\title{
Distributional patterns of macro- and megafauna associated with a reef of the cold-water coral Lophelia pertusa on the Swedish west coast
}

\author{
L. G. Jonsson ${ }^{1,2, *}$, P. G. Nilsson ${ }^{1,2}$, F. Floruta ${ }^{1,2}$, T. Lundälv ${ }^{2}$ \\ ${ }^{1}$ Department of Marine Ecology, Göteborg University, ${ }^{2}$ Tjärnö Marine Biological Laboratory, 45296 Strömstad, Sweden
}

\begin{abstract}
In this study the distributional pattern of the macro- and megafauna of a small (ca. $300 \mathrm{~m}^{2}$ ) Lophelia pertusa (L., 1758) reef was studied with a ROV (remotely operated vehicle). The reef is situated in a shallow fjord off the Swedish west coast. The number of taxa and their abundance in transects from the reef itself and from 3 zones (Zone $1=50 \mathrm{~m}$, Zone $2=100 \mathrm{~m}$ and Zone $3=200 \mathrm{~m}$ ) around the reef were compared. Both the number of taxa (from 30 to 33 transect $^{-1}$ ) and the abundance of individuals (from 21 to $7 \mathrm{~m}^{-2}$ ) decreased with increasing distance from the reef. Divided into ecological guilds, predators and filter-feeders decreased with distance from the reef (predators from 7 to 0.3 ind. $\mathrm{m}^{-2}$, and filter-feeders from 13 to 6 ind. $\mathrm{m}^{-2}$ from Zone 0 to Zone 3), while deposit-feeders increased with increasing distance from 0.04 to 0.4 ind. $\mathrm{m}^{-2}$ from Zone 0 to Zone 3. Sessile species decreased more with increasing distance than mobile species, from 19 to 7 ind. $\mathrm{m}^{-2}$ and from 1 to 0.7 ind. $\mathrm{m}^{-2}$, respectively. Our results also show that small deep-water coral reefs enhance local biodiversity, but the advantage to individual species depends on their mode of feeding and mobility.
\end{abstract}

KEY WORDS: Lophelia pertusa $\cdot$ Associated fauna $\cdot$ Remotely operated vehicle $\cdot$ Deep-water coral

\section{INTRODUCTION}

Tropical coral reefs in shallow waters harbour a rich diversity of associated flora and fauna. During the last decade, the importance of temperate deep-water coral reefs as areas of an almost equally high biodiversity has been established (Jensen \& Frederiksen 1992, Rogers 1999, Reed 2002).

The fauna associated with the deep-water coral Lophelia pertusa (L., 1758) has been investigated by various authors using different methods. For example, Jensen \& Frederiksen (1992) used a triangular dredge and a shell dredge to sample 25 blocks of live and dead L. pertusa on the Faeroe shelf. They examined each block for associated fauna and found 4626 individuals of 256 species, which represented an overall diversity index of 5.50 (Shannon-Wiener diversity index); this is similar to or higher than the diversity found for the associated fauna of zooxanthellate hermatypic tropical corals (Rogers 1999). Mortensen (1993) used an ROV (remotely operated vehicle) in his investigation of the associated megafauna at the $L$. pertusa reef between the Halten and Froeya banks along the Norwegian coast. He made a quantitative study of the fauna and compared the abundances on a soft-bottom, a mixed stone-bottom, L. pertusa rubble, dead L. pertusa and live L. pertusa. He found a fauna with 3 times higher diversity associated with $L$. pertusa compared to the fauna on the surrounding soft-bottoms. Lophelia pertusa rubble was inhabited by the lowest number of taxa (15 taxa) but the highest density of individuals. Fosså \& Mortensen (1998) compiled a list of 744 species from 6 investigations (Dons 1944, Burdon-Jones \& TambsLyche 1960, Jensen \& Frederiksen 1992, Mortensen et al. 1995, Fosså \& Mortensen 1998 [2 investigations]) of associated fauna on $L$. pertusa reefs in the Northeast Atlantic Ocean, displayed in a graph showing the number of species as a function of number of investigations. The curve showed no tendency to level off, indicating that the number of species associated with L. pertusa 
reefs is considerably higher than found so far in the Northeast Atlantic Ocean. Another deep-water hermatypic coral, Oculina varicosa, also supports profuse communities of associated fauna, with a diversity equivalent to that of many shallow-water tropical reefs (Reed 2002). The earlier studies (Jensen \& Frederiksen 1992, Mortensen 1995, Fosså \& Mortensen 1998) all showed evidence of an enhanced biodiversity on $L$. pertusa reefs compared to the surrounding sea bottoms. However, none of these investigations studied how the distribution pattern of the associated fauna varied as a function of distance from an L. pertusa reef. The objective of the present study was to investigate the pattern of this variation among benthic fauna (i.e. macro- and megafauna) by in situ video recordings.

The Lophelia pertusa reef in the study area is situated on a sill in a narrow sound. The bottom substrate of the whole sill (including the coral patches situated on 2 small mounds) consists of gravel and boulders. Therefore, any differences in the associated fauna should be related to the coral framework itself and/or to differences in the current regime between the reef and the surrounding sill, but not to major differences in the bottom substrate. Based on earlier investigations (Jensen \& Frederiksen 1992, Mortensen 1993, Fosså \& Mortensen 1998, Rogers 1999), our a priori hypothesis was that the number of

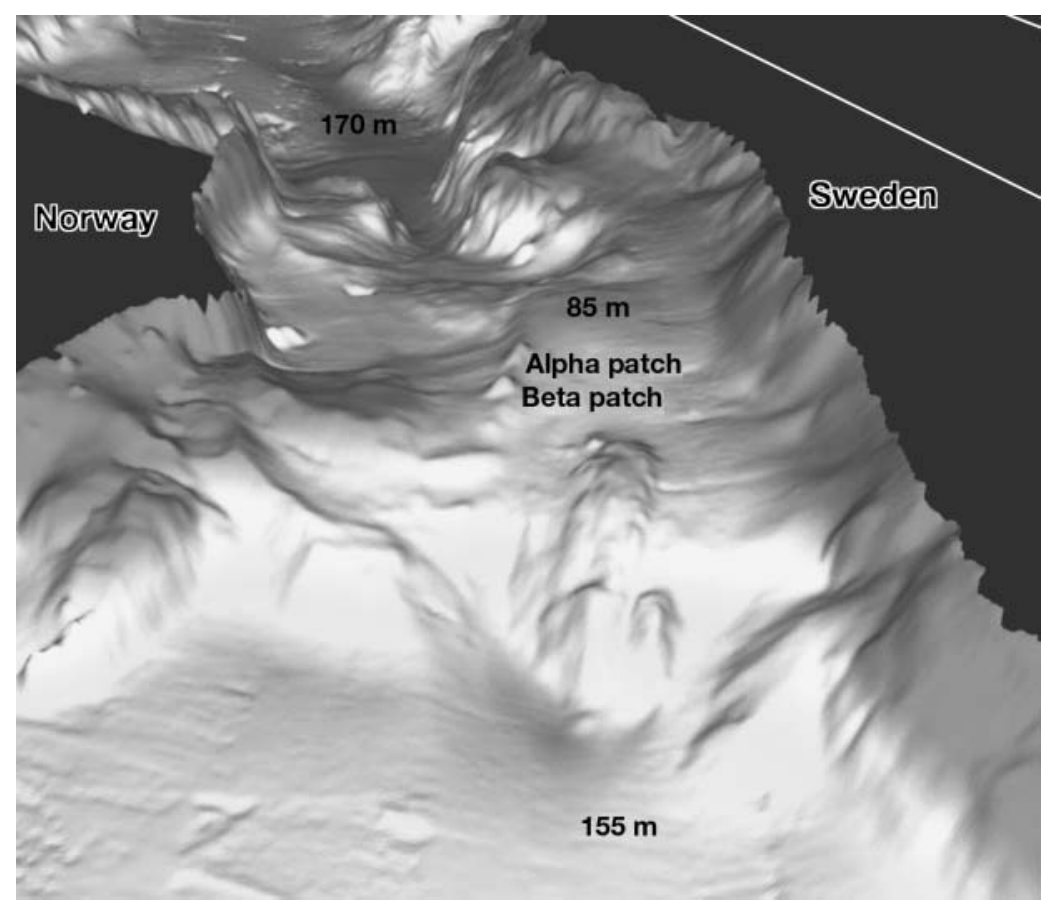

Fig. 1. A 3-dimensional map of the sound between Norway and Sweden in the Northern Kosterfjord showing sill where the Lophelia pertusa reef is situated. The reef, divided into 2 patches (alpha and beta), is situated on the SW bases of 2 small hills. Distance between patches is ca. $100 \mathrm{~m}$. Depths of the sill and softbottom basins north and south of the sill are shown species and their abundance would be higher on the reef than in the surrounding area and would decline with increasing distance from the reef. We also tested additional hypotheses about the response of different ecological guilds, dividing the fauna into mobile and sessile species. Based on the preference for and dependence of filter-feeders on high current regimes, filter-feeders were expected to decline with increasing distance from the reef, to a higher degree than predators. Predators gather in areas of high prey densities, e.g. coral reefs, but are not solely dependent on such areas. In contrast to filter-feeders, deposit-feeders should increase with increasing distance, as they prefer low current regimes in which deposition occurs. Generalistic omnivores are expected to be less influenced by the reef than the other groups. Sessile species were expected to decline to a higher degree than mobile species with increasing distance from the reef.

\section{MATERIALS AND METHODS}

Study area. The study was conducted in the northern part of the Koster fjord off the Swedish west coast. A small Lophelia pertusa reef is located at a depth of 82 to $87 \mathrm{~m}$ on a sill in a narrow sound between Sweden and Norway, Latitude $59^{\circ} 00.82^{\prime} \mathrm{N}$, Longitude $11^{\circ} 06.96^{\prime} \mathrm{E}$ (Fig. 1). The substrate of the sill is made up of gravel, stones and boulders. Deep (155 to $170 \mathrm{~m}$ ) mud-bottom basins are located north and south of the sill. The dominating direction of the bottom current is NNW, with moderately strong currents (0.09 to $\left.0.24 \mathrm{~m} \mathrm{~s}^{-1}\right)$, caused by the general current circulation patterns and topography of the area and by the semidiurnal tidal current. The bottom currents are intensified when flowing over the narrow sill. The reef itself consists of 2 patches, 'alpha' and 'beta'. They are situated at the southwest bases of 2 small mounds on the sill. The distance between the patches is about $100 \mathrm{~m}$. The mounds are composed mostly of $L$. pertusa rubble and densely packed silty clay (particle size 0.002 to $0.06 \mathrm{~mm}$ ) with an average water content of $44 \%$. The patches consist of numerous small coral colonies with $L$. pertusa rubble, gravel, stones and dead L. pertusa colonies in between. Alpha is the northernmost patch with about 150 discrete colonies covering $200 \mathrm{~m}^{2}$; the beta patch is considerably smaller $\left(100 \mathrm{~m}^{2}\right)$ with about 50 colonies. 
The 2 mounds upon which Lophelia pertusa grows form the peaks of the sill. According to Genin et al. (1986), the mean total current speed near a peak is about twice the mean speed at the same depth on a mid-slope site. The location of the L. pertusa reef is therefore within where the strongest currents, in accordance with the observations of Genin et al. (1986).

Data sampling. The patches were considered to constitute 2 centre points (Zone 0) with 3 further zones radiating from them at distances of ca. 50, 100 and $200 \mathrm{~m}$ (Zones 1 to 3) (Fig. 2). The bottom substrates in the zones were live Lophelia pertusa colonies mixed with dead L. pertusa, gravel and boulders in Zone 0, L. pertusa rubble, gravel and boulders in Zone 1, and gravel and boulders in Zones 2 and 3. In each zone of each patch, 2 transects were video-taped, i.e. 16 transects in all. The exact location of each transect was randomly chosen. The area between the 2 coral patches was not included to avoid a possible concurrent effect of the patches on the associated fauna. The lengths of the transects were calculated from the differential GPS positions recorded at the beginning and end of each transect, ranging between 12 and $54 \mathrm{~m}$ at depths between 75 and $92 \mathrm{~m}$. A total of $443 \mathrm{~m}$ of transects were video-taped, covering $265.8 \mathrm{~m}^{2}$.

ROV technology. A Deep Ocean Engineering Phantom XTL ROV equipped with a Sony EVI 331 S-VHS camera with a $12 \times$ zoom lens was used. The filmed area was measured with 2 laser lights, and the video signal was transmitted via a cable from the underwater unit to the deck unit and displayed on the monitor in real-time. The navigational system consisted of a Simrad HPR 410P underwater positioning system, a GBX Pro dGPS and a Robertson rate gyro, giving the position of the ROV with a maximum error of ca. $5 \mathrm{~m}$. All positioning data were integrated in Olex navigational software. The ROV moved $0.5 \mathrm{~m}$ above the sea floor at a speed of about $0.25 \mathrm{~m} \mathrm{~s}^{-1}$.

Fauna analysis. All visible macro- and megafauna in each transect was identified to the lowest possible taxon and counted. The area covered by each transect was calculated and the number of individuals recalculated as ind. $\mathrm{m}^{-2}$. However 2 groups, ascidians and crinoids, were too numerous to count over the whole transects. Instead, the individuals on 3 randomly picked still-frames from the video tape from each transect were counted, and the total number of individuals was extrapolated from these subsets and recalculated as number of ind. $\mathrm{m}^{-2}$. We identified 3 species of ascidians as Ciona intestinalis, Polycarpa pomaria and Ascidiella aspersa. However, because they were often covered by sediment particles, it was difficult to identify individual ascidians to species, and consequently they were grouped together in our analysis. The crinoids consisted of either Hathrometra sarsi or Antedon petasus. It was not possible to distinguish between the 2 species with certainty on the basis of video-tapes. Previous investigations in the reef area have shown that $H$. sarsi is by far the most common crinoid on the reef, constituting at least $95 \%$ of all individuals. Another group, which was difficult to identify to species, was comprised of pandalid shrimps, whose identifying characters are too small to distinguish on a video-tape. From earlier investigations in the area we know that the most common species are Pandalus borealis, $P$. montagui and $P$. propinquus. For colonial species, e.g. Tubularia larynx, Filograna implexa and Serpulidae, whole colonies were counted.

The macro- and megafauna were further divided into mobile (20 taxa) and sessile (27 taxa) groups, and into feeding strategies such as filter-feeders (18 taxa), deposit-feeders (2 taxa), omnivores (10 taxa) and predators (17 taxa) according to the descriptions given by Hansson (1998 and H. G. Hansson pers. comm.).

Statistical analysis. Univariate: Numbers of individuals were analysed using 2-way analysis of variance (ANOVA), with zones and patches as orthogonal factors and transects as replicates. Numbers of taxa were analysed using ANCOVA, with the same main factors but with the length of transects as a covariate. Homogeneity of variances was tested by Cochran's-test, and Student-Newman-Keuls (SNK) tests were used for post-hoc comparisons among zones.

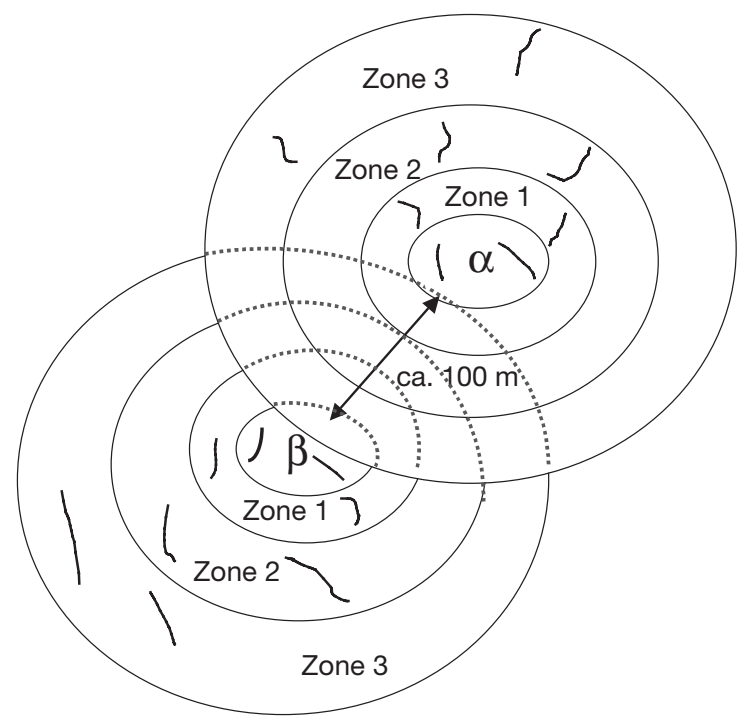

Fig. 2. Field study design: Coral reef patches, alpha and beta, constitute Zone 0 . Zones 1, 2 and 3 are 50, 100 and $200 \mathrm{~m}$ from the patch centre, respectively. Irregular short lines in zone fields represent transects (these are not drawn where they were actually video recorded). In the area between the alpha and beta patches no transects were made, as this area was influenced by both patches 
Table 1. Number of individuals of all observed species. Number of individuals for each pair of transects (see Fig. 2) were added together to give the total for each zone. E: ecological group (f: filter-feeders; p: predators; d: deposit-feeders; o: omnivores)

\begin{tabular}{|c|c|c|c|c|c|c|c|c|c|c|}
\hline \multirow[t]{2}{*}{ Phylum } & \multirow[t]{2}{*}{ E } & \multirow[t]{2}{*}{ Species } & \multicolumn{4}{|c|}{ Alpha patch } & \multicolumn{4}{|c|}{ Beta patch } \\
\hline & & & 0 & 1 & 2 & 3 & 0 & 1 & 2 & 3 \\
\hline \multirow[t]{6}{*}{ Porifera } & $\mathrm{f}$ & Geodia barretti & 2.16 & 0.26 & 0.42 & 0 & 1.01 & 0.38 & 0 & 0.15 \\
\hline & $\mathrm{f}$ & Polymastia spp. & 0 & 0 & 0 & 0 & 0 & 0 & 0 & 0.1 \\
\hline & $\mathrm{f}$ & Phakellia ventilabrum & 0 & 0 & 0.5 & 0 & 0 & 0 & 0 & 0.67 \\
\hline & $\mathrm{f}$ & Mycale lingua & 2.04 & 0 & 0.08 & 0 & 1.05 & 0.39 & 0.21 & 0.3 \\
\hline & $\mathrm{f}$ & Tragosia infundibuliformis & 0 & 0 & 0.74 & 0 & 0 & 0 & 0 & 0.52 \\
\hline & $\mathrm{f}$ & Unidentified sponge & 0 & 0 & 0.53 & 0 & 0 & 0.07 & 0 & 0 \\
\hline \multirow[t]{10}{*}{ Cnidaria } & $\mathrm{p}$ & Actinostola callosa & 0 & 0 & 0.1 & 0 & 0.06 & 0 & 0.15 & 0 \\
\hline & $\mathrm{p}$ & Alcyonium digitata & 0.05 & 0 & 0 & 0 & 0 & 0 & 0.04 & 0 \\
\hline & $\mathrm{p}$ & Bolocera tuediae & 0.62 & 1.13 & 0.08 & 0 & 1.59 & 0.54 & 0.3 & 0 \\
\hline & $\mathrm{p}$ & Hormathia digitata & 0 & 0.12 & 0.21 & 0.17 & 0.08 & 0.07 & 0 & 0 \\
\hline & $\mathrm{p}$ & Protanthea simplex & 10.51 & 1.81 & 0 & 0 & 7.26 & 1.99 & 0 & 0 \\
\hline & $\mathrm{p}$ & Urticina eques & 0 & 0 & 0 & 0 & 0 & 0 & 0 & 0.04 \\
\hline & $\mathrm{p}$ & Eudendrium rameum & 0.08 & 0 & 0 & 0 & 0.06 & 0 & 0 & 0 \\
\hline & $\mathrm{p}$ & Tubularia indivisa & 0.81 & 3.1 & 0 & 0 & 0 & 7.02 & 0 & 0 \\
\hline & $\mathrm{p}$ & Tubularia larynx ${ }^{\mathrm{a}}$ & 0.15 & 2.65 & 0 & 0 & 0 & 1.55 & 0 & 0 \\
\hline & $\mathrm{p}$ & Unidentified hydroid & 1.83 & 1.66 & 0.47 & 0.49 & 0.41 & 1.16 & 0.24 & 0 \\
\hline \multirow[t]{5}{*}{ Annelida } & $\mathrm{f}$ & Branchiomma bombyx & 0.13 & 0 & 0 & 0 & 0.08 & 0 & 0 & 0 \\
\hline & $\mathrm{f}$ & Filograna implexa & 0.38 & 2.18 & 1.66 & 1.51 & 1.61 & 1.7 & 0.07 & 0.67 \\
\hline & $\mathrm{f}$ & Myxicola spp. & 1.02 & 0.42 & 0.32 & 0 & 2.88 & 2.01 & 0.24 & 0 \\
\hline & $\mathrm{f}$ & Sabella pavonina & 17.51 & 14.94 & 11.06 & 8.19 & 14.38 & 19.02 & 6.16 & 3.44 \\
\hline & $\mathrm{f}$ & Serpulidae & 0 & 0.24 & 1.54 & 0.17 & 0.17 & 0.22 & 0.71 & 1.06 \\
\hline Echiura & $\mathrm{d}$ & Bonellia viridis & 0.05 & 0.24 & 0.55 & 0.08 & 0.06 & 0.08 & 1.1 & 1.05 \\
\hline \multirow[t]{8}{*}{ Arthropoda } & $\mathrm{o}$ & Cancer pagurus & 0.08 & 0.26 & 0 & 0 & 0 & 0.08 & 0 & 0 \\
\hline & $\mathrm{p}$ & Lithodes maja & 0.15 & 0 & 0 & 0 & 0 & 0.15 & 0.03 & 0.03 \\
\hline & $\mathrm{p}$ & Munida rugosa & 1.83 & 1.17 & 1.26 & 0.17 & 1.09 & 0.71 & 0.51 & 0.26 \\
\hline & $\mathrm{p}$ & Munidopsis serricornis & 0.6 & 0 & 0 & 0 & 0 & 0 & 0 & 0 \\
\hline & o & Paguridae & 0 & 0 & 0.29 & 0 & 0 & 0 & 0.07 & 0.04 \\
\hline & $\mathrm{o}$ & Pandalus spp. ${ }^{\mathrm{b}}$ & 0.08 & 0 & 0 & 0 & 0.14 & 0 & 0.1 & 0 \\
\hline & $\mathrm{o}$ & Spirontocaris liljeborgi & 0 & 0.78 & 0 & 0.08 & 0.19 & 0.07 & 0.13 & 0 \\
\hline & $\mathrm{p}$ & Unidentified brachyuran & 0 & 0 & 0 & 0 & 0 & 0 & 0 & 0.04 \\
\hline \multirow[t]{4}{*}{ Mollusca } & $\mathrm{p}$ & Unidentified aeolidoid & 0 & 0.56 & 0.08 & 0 & 0 & 0 & 0 & 0 \\
\hline & $\mathrm{o}$ & Buccinum undatum & 0.22 & 0 & 0.24 & 0.25 & 0 & 0 & 0 & 0 \\
\hline & $\mathrm{o}$ & Neptunea antiqua & 0 & 0 & 0.37 & 0.33 & 0 & 0 & 0.03 & 0.03 \\
\hline & $\mathrm{f}$ & Pseudamussium septemradiatum & 0 & 0 & 0.18 & 0 & 0.06 & 0 & 0.26 & 0.75 \\
\hline \multirow[t]{3}{*}{ Brachiopoda } & $\mathrm{f}$ & Terebratulina retusa & 4.6 & 1.37 & 5.28 & 0.08 & 3.03 & 2.67 & 3.64 & 2.48 \\
\hline & $\mathrm{f}$ & Macandrevia crania & 1.03 & 0.28 & 3.55 & 0.08 & 0.83 & 1.4 & 1.06 & 3.07 \\
\hline & $\mathrm{f}$ & Neocrania anomala & 0 & 0 & 0.08 & 0.42 & 0 & 0 & 0 & 0 \\
\hline Bryozoa & $\mathrm{f}$ & Reteporella beaniana & 0 & 0 & 0.08 & 0 & 0 & 0 & 0 & 0 \\
\hline \multirow[t]{6}{*}{ Echinodermata } & $\mathrm{f}$ & Crinoidea $^{\mathrm{C}}$ & 119 & 43.63 & 93.7 & 51.26 & 77.8 & 66.7 & 120.7 & 3.08 \\
\hline & $\mathrm{o}$ & Echinus esculentus & 0 & 0 & 0 & 0 & 0.14 & 0 & 0 & 0 \\
\hline & $\mathrm{o}$ & Henricia spp. & 0.73 & 0.8 & 0.71 & 0 & 0.32 & 0.46 & 0.07 & 0.04 \\
\hline & $\mathrm{d}$ & Mesothuria intestinalis & 0 & 0 & 0 & 0.08 & 0.06 & 0 & 0 & 0.25 \\
\hline & $\mathrm{o}$ & Unidentified ophiuroid & 0 & 0.14 & 0.1 & 0.17 & 0 & 0.07 & 0 & 0 \\
\hline & $\mathrm{o}$ & Porania pulvillus & 0 & 0 & 0 & 0 & 0 & 0.07 & 0 & 0 \\
\hline \multirow[t]{3}{*}{ Chordata } & $\mathrm{f}$ & Ascidiacea $^{\mathrm{d}}$ & 100 & 124 & 333 & 1.92 & 101.6 & 166.3 & 4.62 & 17.43 \\
\hline & $\mathrm{p}$ & Gadus morhua & 0.1 & 0.12 & 0.16 & 0.08 & 0.08 & 0.07 & 0 & 0 \\
\hline & $\mathrm{p}$ & Lycodes vahli & 0 & 0 & 0 & 0.08 & 0 & 0 & 0 & 0 \\
\hline $\begin{array}{l}{ }^{\mathrm{a}} \text { Colonial specie } \\
{ }^{\mathrm{b}} \text { Group pandalic } \\
{ }^{\mathrm{c}} \text { Group crinoide } \\
{ }^{\mathrm{d}} \text { Group ascidiac }\end{array}$ & $\begin{array}{l}\text { S for } \\
\text { ls } \mathrm{Co} \\
\mathrm{a} \mathrm{co} \\
\mathrm{ea} \mathrm{C}\end{array}$ & $\begin{array}{l}\text { which colonies and not individuals } \\
\text { isists of Pandalus borealis, P. propi } \\
\text { sists of Hathrometra sarsi and Ante } \\
\text { nsists of Ciona intestinalis, Polycar }\end{array}$ & $\begin{array}{l}\text { were c } \\
\text { inquus } \\
\text { redon pe } \\
\text { pom }\end{array}$ & $\begin{array}{l}\text { and } P \cdot m \\
\text { andasus } \\
\text { laria and }\end{array}$ & Ascidie & lla aspe & & & & \\
\hline
\end{tabular}


Multivariate: Clustering, MDS (multidimensional scaling) and ANOSIM (analysis of similarities) analyses were performed on the data using the PRIMER package (Clarke \& Warwick 2001). Clustering aims at finding natural groupings of samples such that samples within a group are more similar to each other, generally, than samples in different groups. The groups are then displayed in a dendrogram by hierarchical agglomerative clustering. Multidimensional scaling produces a map of the samples, in a specified number of dimensions, where the distances between the samples on the map illustrate the degree of similarity between them. The map is then compressed into 2 dimensions. ANOSIM compares the observed differences between sites with the differences among replicates within sites, so that a significant R-value indicates significant differences between sites. Pairwise comparisons between sites were also performed with ANOSIM. Due to a very strong dominance of ascidians and crinoids, the basic data were fourth-root-transformed for the multivariate tests.

\section{RESULTS}

A total of 47 taxa from 10 phyla were observed in the transects (Table 1). A total of 34 taxa could be identified to species level while the remaining were identified to genus or family level, but 5 taxa belonging to sponges, hydroids, brachyurans, aeolidoids and ophiuroids, could not be identified with higher taxonomic resolution. The 2 most common groups were crinoids (35\% of all observed individuals) and ascidians (51\%). The third most common group was polychaetes with $7 \%$. We observed 11 taxa only once or twice along the transects and only 4 taxa were observed in all transects: the polychaetes Filograna implexa and Sabella pavonina, the crinoids and the ascidians. Very few sea anemones were found in Zone 3 compared to the other zones. Fishes were scarce; individuals of 2 species were observed sporadically: cod Gadus morhua and Vahl's eelpout Lycodes vahli.

The total number of taxa found in all transects in each zone varied: 33 taxa on the 2 patches (Zone 0 ), 27 in Zone 1, 33 in Zone 2, and 30 in Zone 3. The total number of taxa per transect differed significantly among zones (ANCOVA, p = 0.01), but this pattern differed between the 2 patches (patch $\times$ zone interaction: $p=0.04)$, being more pronounced in Patch alpha (Fig. 3a).

The total number of individuals showed a significant difference both between patches $(p=0.01)$ and between zones $(p=0.0004)$. However, the strong dominance of ascidians and crinoids masked the distribu-
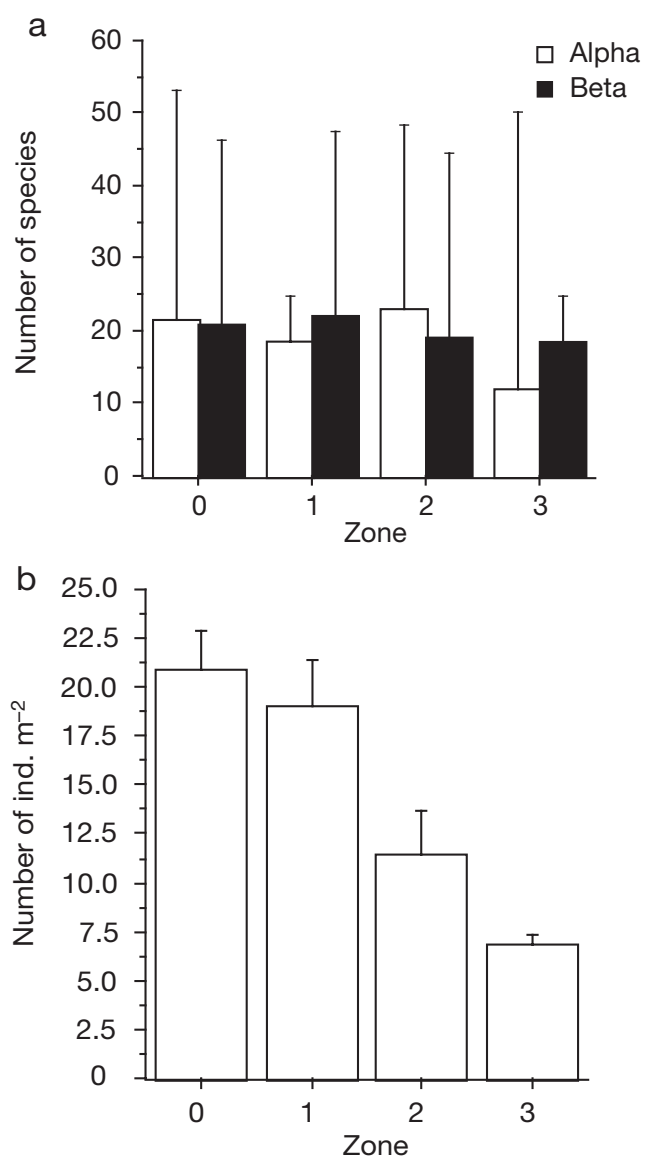

Fig. 3. (a) Number of species in coral reef alpha and beta patches of Lophelia pertusa and in Zones 0 to 3. (b) Number of ind. $\mathrm{m}^{-2}$ in the zones. Error bars show $+95 \%$ confidence limits

tion pattern of the remaining taxa. Thus, these 2 taxa were excluded from all further univariate statistical analyses, but included in all the multivariate analyses. The same test on the total number of individuals without these 2 taxa revealed a significant difference only between zones ( $p=0.0008$ ) (Fig. $3 b$ ), with the number of individuals decreasing from 21 ind. $\mathrm{m}^{-2}$ in Zone 0 to 7 ind. $\mathrm{m}^{-2}$ in Zone 3 . The SNK-test showed that Zones 0 and 1 were significantly different from Zone 2 and 3. The multivariate test ANOSIM detected significantly larger differences between zones than between transects $(R=0.56, p=0.001)$. Pairwise comparisons between the zones showed that Zones 0 and 1, Zones 0 and 2, and Zones 1 and 2 were well separated $(\mathrm{R}>$ 0.75), Zones 0 and 3, and Zones 1 and 3 were overlapping but clearly different $(\mathrm{R}>0.4)$, while Zones 2 and 3 were almost identical $(\mathrm{R}<0.25)$.

When the number of individuals of the various species was grouped into sessile or mobile species, the distribution patterns of the 2 groups differed (interaction zone $\times$ mobile/sessile group $p=0.0001$ ). 
The abundance of mobile organisms was higher in the alpha patch than in the beta patch $(p=0.006)$, with 1.5 and 0.8 ind. $\mathrm{m}^{-2}$, respectively, but with no significant difference between zones. The sessile species decreased significantly with increasing distance from the reef $(\mathrm{p}=0.0006)$ from 19 ind. $\mathrm{m}^{-2}$ in Zone 0 to 7 ind. $\mathrm{m}^{-2}$ in Zone 3, but showed no difference between the patches.

The patterns for the groups of different feeding strategies also changed over the zones (interaction zone $\times$ feeding strategy $p=0.0001)$. Predators decreased with increasing distance from the reef $(\mathrm{p}=$ 0.005) and showed a particularly strong decline between Zones 1 and 2 from 6 to 0.9 ind. $\mathrm{m}^{-2}$ (Fig. 4a).

Filter-feeders also decreased with increasing distance from the reef ( $p=0.0007)$ (Fig. 4b) from 14 ind. $\mathrm{m}^{-2}$ in Zone 0 to 6 ind. $\mathrm{m}^{-2}$ in Zone 3, but the pattern was different for the 2 patches (interaction zone $\times$ patch $\mathrm{p}=0.006$ ): Zone 0 and 2 of the alpha patch contained more individuals than Zones 1 and 3, while Zones 0 and 1 of the beta patch had more individuals than Zone 2 and 3. A SNK-test showed significant differences between all zones in both patches, but when zones were compared between the patches only Zones 1 and 2 differed.
Deposit-feeders were more common in the beta patch than in the alpha patch $(\mathrm{p}=0.01)$, with 0.3 and 0.1 ind. $\mathrm{m}^{-2}$ respectively, and had a higher number of individuals in Zones 2 and 3 than in either Zones 0 or 1 $(p=0.004$ ) (Fig. 4c). The highest numbers of individuals were found in Zone 2 in the alpha patch and Zone 3 in the beta patch (interaction patch $\times$ zone $\mathrm{p}=0.02$ ). SNK-tests showed significant differences between zones only in the beta patch. Only Zones 2 and 3 differed significantly between patches.

Finally, more omnivores were found in the alpha patch than in the beta patch $(p=0.005)$ with 0.7 and 0.3 ind. $\mathrm{m}^{-2}$, respectively, but there was no significant difference between zones (Fig. 4d).

In the multivariate analysis the dendrogram for the hierarchical clustering distinguished between 2 blocks (Fig. 5), one comprised of Zone 0 and 1 at the $68.7 \%$ similarity level, and the other comprised the 2 zones furthest away from the reef at a similarity level of $63.79 \%$. However, Zone 3 in the alpha patch was excluded from the blocks, as the fauna assemblage in this zone differed from all other zones. Two subsets, the transects of Zones 0 and 2 had similarity levels of 76.1 and $67.5 \%$, respectively. The MDS ordination plot in Fig. 6 illustrates how the species assemblages
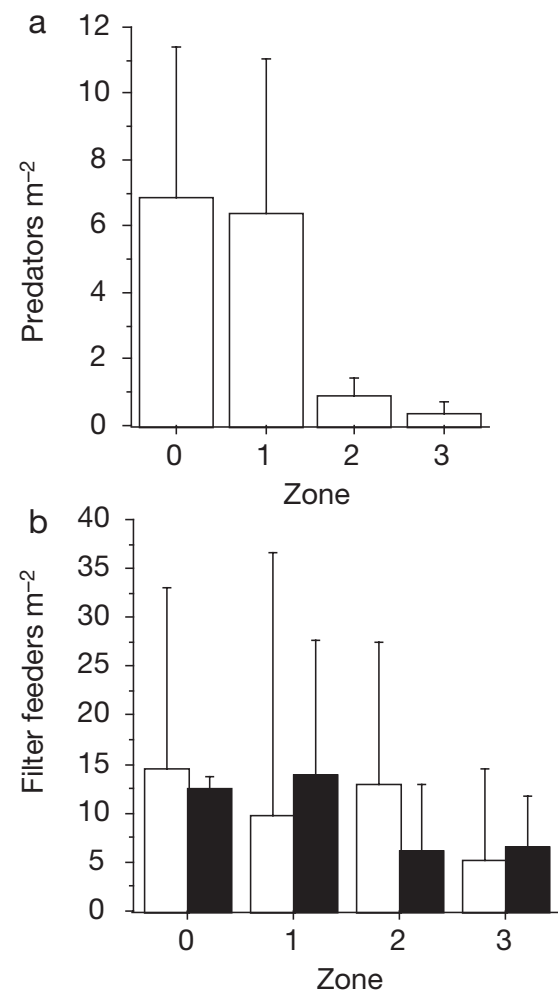
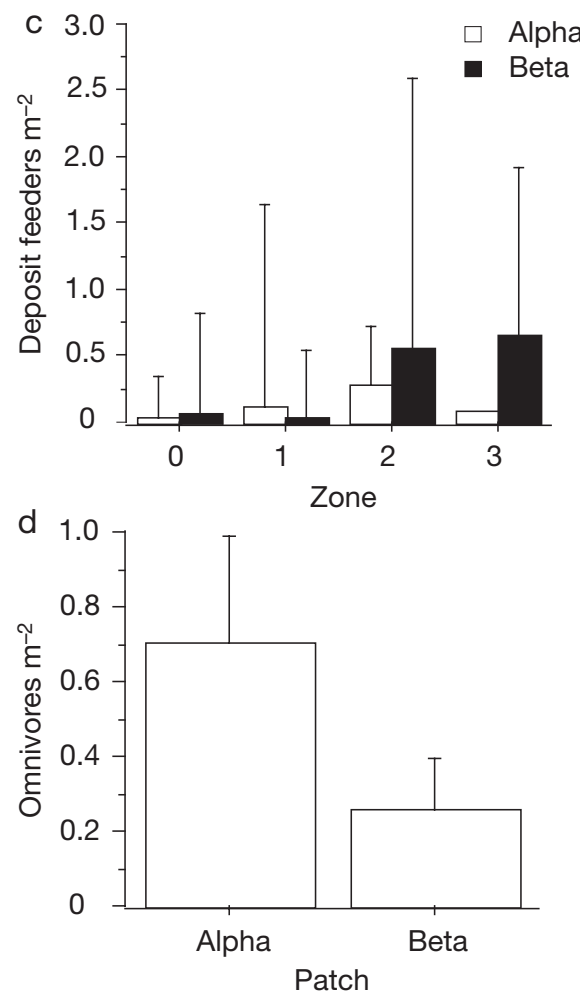

Fig. 4. Number of individuals of different feeding strategies in Lophelia pertusa patches/zones. (a) Predators in the 4 zones. (b) Filter-feeders in the 2 patches and 4 zones. (c) Deposit-feeders in the 2 patches and 4 zones. (d) Omnivores in the 2 patches. Error bars show $+95 \%$ confidence limits 


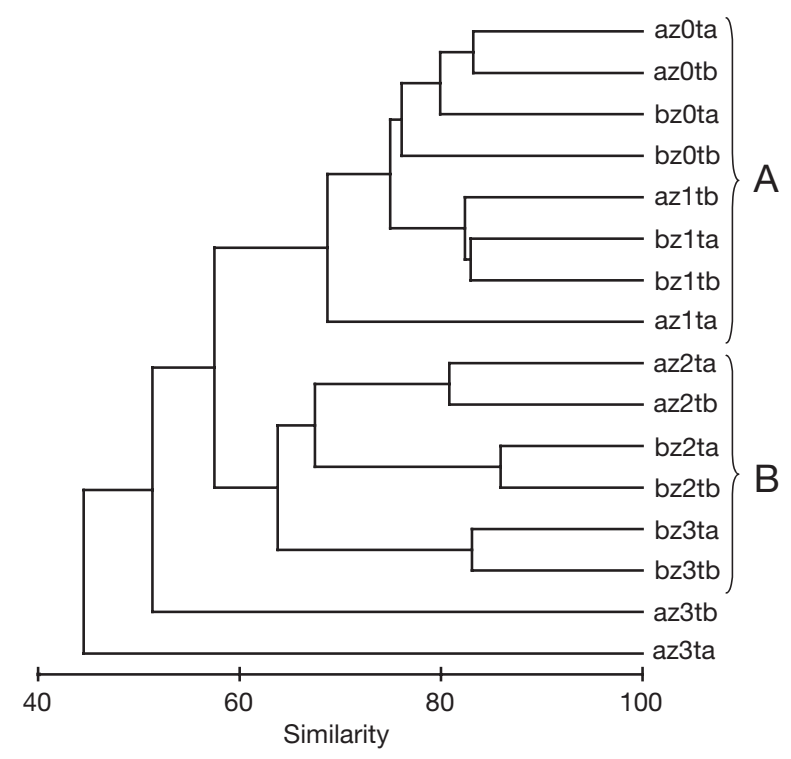

Fig. 5. Dendrogram showing percentage similarity of species assemblages between transects on and around patches. Cluster A: Zones 0 and 1; Cluster B: Zones 2 and 3; a: alpha patch; b: beta patch; z: zone; ta and tb: 2 transects in the alpha and beta patches

in the 4 transects in each zone decreased their similarities with increasing distance from the reef (see increased scatter of symbols from Zone 0 to Zone 3 in Fig. 6).

\section{DISCUSSION}

Our study showed that the fauna is strongly influenced by the presence of the coral reef: the number of taxa and the abundance of individuals changed significantly with increasing distance from the reef. However, the change was not necessarily a sudden change from the coral reef itself to the surrounding area, but often a gradual change with increasing distance from the reef (see Fig. 4). The smallest number of taxa (27) was found in Zone 1, where the bottom substrate was dominated by coral rubble. This is analogous to the results of Mortensen et al.'s (1995), who found less taxa in areas with Lophelia pertusa rubble. Based on their dependence of the structure of the coral reef, we expected filter-feeders, predators, deposit-feeders and omnivores, to differ in their distribution pattern on the reef and in the surrounding area. This was indeed the case (Fig. 4): abundance of predators and filter-feeders decreased with increasing distance from the reef, while that of deposit-feeders increased, and omnivores showed no apparent pattern as a function of distance from the reef. The clearest pattern was the strong decline in predators

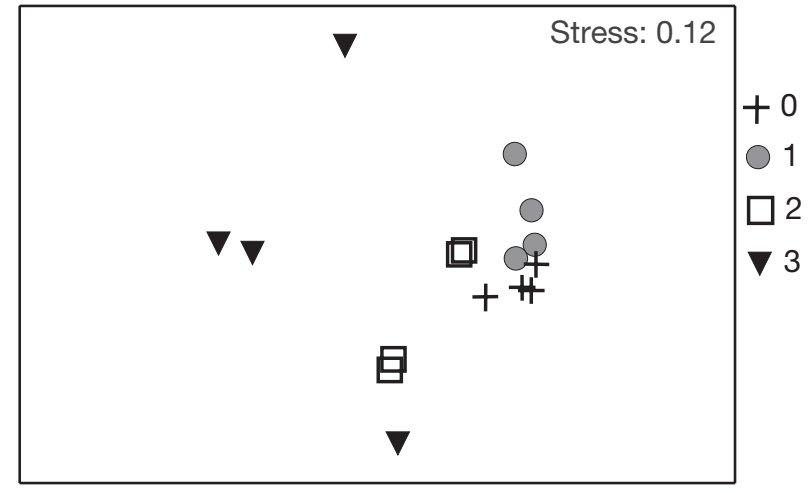

Fig. 6. Two-dimensional MDS ordination plot showing similarity of associated species in transects in Zones 0 to 3 in the alpha and beta patches

between Zone 1 and 2 (Fig. 4a). Lenihan \& Micheli (2001) suggested that the heterogenous reef habitat may provide refuge and also facilitate predation. In our study the abundance of predators appeared to be promoted both by the coral reef and the coral rubble, in contrast to the more homogenous bottom in Zones 2 and 3. Furthermore, the L. pertusa colonies, both living and dead, provide a stable substrate area which probably facilitates settling of hydroids and the sea anemone Protanthea simplex. These sessile predators showed a strong decline in abundance from the reef area to the outer zones. The distributional pattern of deposit-feeders displayed a very strong positive correlation with increasing distance from the reef, although this must be viewed with caution, as it is based on only a few individuals belonging to 2 species. The presence of so few individuals is explained by the fact that as a whole the sill area is unsuitable for deposit-feeders except for small pockets of substrate protected from the currents.

Two groups, mobile species and the omnivores, were present in higher abundance in the alpha patch, but with no difference between zones. Patch alpha is about twice the size of Patch beta (200 vs $100 \mathrm{~m}^{2}$ ). It is possible that, for mobile species and omnivores the advantages provided by the reef is dependent on the size of the reef but not on distance from the reef. However, since we do not have replicates for the size of reefs, we can draw no conclusions about this based on our material. For other groups such as sessile species, predators and filter-feeders, there seems to be a positive effect centred on the reef area itself, which decreases with increasing distance from the reef. The benefits appear to be directly connected to the presence of a suitable substrate, such as an elevated hard-bottom exposed to strong currents, or to the physical complexity of the habitat. 
An univariate post-hoc SNK test revealed that the number of individuals in Zones 0 and 1 significantly different from that in Zones 2 and 3. A multivariate ANOSIM test, on the other hand, found significant differences between all zones. The latter compared the zones on an individual species basis, in contrast to the former, in which the species assemblage for each zone was compared as a total. Zones 1 and 2 differed, while the differences between Zones 2 and 3 were much smaller. Our conclusion is that the reef itself and its immediate vicinity (Zones 0 and 1 ) show not only differences in number of taxa and number of individuals, but also in taxa composition compared to the surrounding area (Zones 2 and 3). This result indicates the importance of not only live Lophelia pertusa (in Zone 0), but also coral rubble (Zone 1).

Mortensen et al. (1995) found that diversity increased gradually from the up-current to the downcurrent side of their study reef. In our study, no such differences were discernible between the 2 patches. The transects around the alpha patch were essentially north of the patch, while the transects around the beta patch were basically south of the patch (Fig. 2). Although the dominating direction of the current was NNW, the semidiurnal tide changed direction consistently, which probably counteracted any directional effects of currents on the associated fauna.

In this study, 2 conspicuous characteristics of the Lophelia pertusa reef were the low diversity (2 species) and abundance of fishes, in contrast to the observations in other studies (Mortensen 1993, Mortensen et al, 1995, Fosså et al, 2000), and the high abundance of crinoids and ascidians. On Norwegian L. pertusa reefs, Norway haddock Sebastes viviparus in particular is extremely common. A feasible explanation for the lack of fishes found in our study is that the fish stock in the Koster fjord area has declined dramatically over the last few decades, as evidenced by decreasing catches by local fishermen (including the bycatch of shrimp trawls). During previous surveys on the L. pertusa reef in the Koster fjord, we observed a total of 10 fish species during $30 \mathrm{~h}$ of video-recording. During our ROV-surveys of other areas of the Koster fjord, the abundance of fishes has been similarly low. On Norwegian $L$. pertusa fjord reefs, only occasional individuals of crinoids and even fewer ascidians, have been observed, compared to the Swedish reef in our study. We observed a rather high amount of particles in the water column (0.29 to 4.56 nephelometric turbidity units [NTU] with a mean of 0.54 NTU) when filming with the ROV and this may explain the high abundances of these 2 groups in the Swedish L. pertusa reef area.

The fauna associated with both Lophelia pertusa and Oculina varicosa has been shown to diverge highly between different sampling sites (Rogers 1999). Rogers (1999) argued that the species composition of the associated fauna is influenced by local physical and biological factors, and therefore reflect the local fauna. A striking example of this is the total absence of gorgonians from the L. pertusa reef in our study, and also in the rest of the fjord. In western Norway, on the other hand, gorgonians are commonly observed, and these are also common on Norwegian $L$. pertusa reefs (Fosså \& Mortensen 1998). Similar to the situation in Norwegian fjords (Mortensen \& Fosså 2001), hydroids were common among the coral colonies on the L. pertusa reef in Koster fjord, while on the Faeroe shelf hydroids were uncommon. In the area around the Faroes the hydrozoans are smaller and more poorly developed than in Norwegian fjords (Jensen \& Frederiksen 1992).

Our results strongly indicated that Lophelia pertusa is important as a foundation species (Bruno \& Bertness 2001). Even a very small reef, such as that in this study, clearly increases abundances in the area of the reef and the sea bottom immediately adjacent to the reef. However, we found some differences between the 2 patches examined that raise questions about the effect of reef size on associated fauna. It would be interesting to compare the results from this small reef with results from larger reefs. On the Swedish west coast, living $L$. pertusa coral was previously (in the 1970s) reported from a site $35 \mathrm{~km}$ to the south of the reef in our study, but during recent ROV investigations we found only dead corals and coral rubble at that site. However, a much larger reef has recently been discovered south of the Hvaler Islands in Norwegian waters, only about $10 \mathrm{~km}$ from the reef in Northern Koster fjord. The bottom topography of this larger reef is very similar to that of the reef in our study, as both reefs are situated on sills in a deep trough; however, the Norwegian reef covers an area of about $250000 \mathrm{~m}^{2}$ compared to the ca. $300 \mathrm{~m}^{2}$ of our study reef.

In many areas throughout the world, deep-water reefs are under imminent threats from, for example, fishing, oil exploration and changed sedimentation regimes. Our study shows the importance of these reefs, not only for the organisms living directly on the reef, but also for mobile organisms living outside but near the reefs. The effect of structure and size of individual reefs, and the connectivity between different reefs, are important issues that must be studied in order to formulate efficient conservation policies for deep-water reefs.

Acknowledgements. The study was partly financed by ACES (Atlantic Coral Ecosystem Studies) and Centrum för biologisk mångfald (Centre of biodiversity). We thank Professor K. Johannesson for valuable comments on the manuscript. 


\section{LITERATURE CITED}

Bruno JF, Bertness MD (2001) Habitat modification and facilitation in bentic marine communities. In: Bertness MD, Gaines SD, Hay ME (eds) Marine community ecology. Sinauer Associates, Sunderland, MA, p 201-218

Burdon-Jones C, Tambs-Lyche H (1960) Observations on the fauna of the North Brattholmen stone-coral reef near Bergen. Årbok for Universitetet i Bergen. Mat.-naturv. Serie 1960 (4):1-24

Clarke KR, Warwick RM (2001) Change in marine communities: an approach to statistical analysis and interpretation, 2nd edn. National Environment Research Council, Cambridge, UK

Dons C (1944) Norges korallrev. Det Kongelige Norske Videnskabers Selskabs Forhandlinger 16:37-82

Fosså JH, Mortensen PB (1998) Artsmangfoldet på Lopheliakorallrev og metoder for kartlegging og overvåkning. Fisken Havet 17:1-95 (in Norwegian with English Abstract)

Fosså JH, Mortensen PB, Furevik DM (2000) Lophelia to korallrev langs norskekysten. Forekomst og tillstand, Institute of Marine Fisheries project report. Fisken havet 2:1-87 (in Norwegian with English Abstract)

Genin A, Dayton PK, Lonsdale PF, Spiess FN (1986) Corals on seamount peaks provide evidence of current acceleration over deep-sea topography. Nature 322:59-61

Editorial responsibility: Otto Kinne (Editor), Oldendorf/Luhe, Germany
Hansson HG (1998) Sydskandinaviska marina flercelliga evertebrater. Västra Götaland County administration Report No 1998:4, Miljöavdelningen, Göteborg. Göteborgs Länstryckeri $\mathrm{AB}$

Jensen A, Frederiksen R (1992) The fauna associated with the bank-forming deep-water coral Lophelia pertusa (Scleractinaria) on the Faroe shelf. Sarsia 77:53-69

Lenihan HS, Micheli F (2001) Soft-sediment communities In: Bertness MD, Gaines SD, Hay ME (eds) Marine community ecology, Sinauer Associates, Sunderland, MA, p 253-287

Mortensen PB (1993) Fauna på Lophelia-rev mellom Haltenog Fröyabanken. Institute of Marine Fisheries Report No 36, Deptartment of Fisheries and Marine Biology, Bergen Mortensen PB, Fosså JH (2001) Korallrev og andre bunnhabitater på Tautraryggen i Trondheimsfjorden. Institute of Marine Research, Rep No 2001 (7) Fiskenog Havet

Mortensen PB, Hovland M, Brattegard T, Farestveit R (1995) Deep water bioherms of the scleractinian coral Lophelia pertusa (L.) at $64^{\circ} \mathrm{N}$ on the Norwegian shelf: structure and associated megafauna. Sarsia 80:145-158

Reed JK (2002) Comparison of deep-water coral reefs and lithoherms off southeastern USA. Hydrobiologia 471: $57-69$

Rogers AD (1999) The biology of Lophelia pertusa (Linnaeus 1758) and other deep-water reef-forming corals and impacts from human activities. Int Rev Hydrobiol 84: 315-406

Submitted: December 12, 2002; Accepted: March 16, 2004 Proofs received from author(s): November 30, 2004 